\title{
Driving forces of mid-Holocene vegetation shifts on the upper Tibetan Plateau, with emphasis on changes in atmospheric $\mathrm{CO}_{2}$ concentrations
}

\author{
Ulrike Herzschuh $^{\mathrm{a}, \mathrm{b}, *}$, Jian $\mathrm{Ni}^{\mathrm{a}}$, H. John B. Birks ${ }^{\mathrm{c}, \mathrm{d}, \mathrm{e}}$, Jürgen Böhner ${ }^{\mathrm{f}}$ \\ a Alfred Wegener Institute for Polar and Marine Research, Research Unit Potsdam, Germany \\ ${ }^{\mathrm{b}}$ Department of Earth and Environmental Sciences, University of Potsdam, Germany \\ ${ }^{\mathrm{c}}$ Department of Biology, Bjerknes Centre for Climate Research, University of Bergen, Norway \\ ${ }^{\mathrm{d}}$ Environmental Change Research Centre, University College London, UK \\ e School of Geography and the Environment, University of Oxford, UK \\ ${ }^{\mathrm{f}}$ Institute of Geography, Hamburg University, Germany
}

\section{A R T I C L E I N F O}

\section{Article history:}

Received 18 December 2009

Received in revised form

11 March 2011

Accepted 14 March 2011

Available online 17 May 2011

\section{Keywords:}

Tibetan Plateau

Pollen

Holocene

Transfer function

Kobresia meadow

Atmospheric $\mathrm{CO}_{2}$ concentration

\begin{abstract}
A B S T R A C T
Numerous pollen records across the upper Tibetan Plateau indicate that in the early part of the midHolocene, Kobresia-rich high-alpine meadows invaded areas formerly dominated by alpine steppe vegetation rich in Artemisia. We examine climate, land-use, and $\mathrm{CO}_{2}$ concentration changes as potential drivers for this marked vegetation change. The climatic implications of these vegetational shifts are explored by applying a newly developed pollen-based moisture-balance transfer-function to fossil pollen spectra from Koucha Lake on the north-eastern Tibetan Plateau $\left(34.0^{\circ} \mathrm{N} ; 97.2^{\circ} \mathrm{E} ; 4540 \mathrm{~m}\right.$ a.s.l.) and Xuguo Lake on the central Tibetan Plateau $\left(31.97^{\circ} \mathrm{N} ; 90.3^{\circ} \mathrm{E} ; 4595 \mathrm{~m}\right.$ a.s.l.), both located in the meadow-steppe transition zone. Reconstructed moisture-balances were markedly reduced (by $\sim 150-180 \mathrm{~mm}$ ) during the early mid-Holocene compared to the late-Holocene. These findings contradict most other records from the Indian monsoonal realm and also most non-pollen records from the Tibetan Plateau that indicate a rather wet early- and mid-Holocene. The extent and timing of anthropogenic land-use involving grazing by large herbivores on the upper Tibetan Plateau and its possible impacts on highalpine vegetation are still mostly unknown due to the lack of relevant archaeological evidence. Arguments against a mainly anthropogenic origin of Kobresia high-alpine meadows are the discovery of the widespread expansion of obviously 'natural' Kobresia meadows on the south-eastern Tibetan Plateau during the Lateglacial period indicating the natural origin of this vegetation type and the lack of any concurrence between modern human-driven vegetation shifts and the mid-Holocene compositional changes. Vegetation types are known to respond to atmospheric $\mathrm{CO}_{2}$ concentration changes, at least on glacial-interglacial scales. This assumption is confirmed by our sensitivity study where we model Tibetan vegetation at different $\mathrm{CO}_{2}$ concentrations of 375 (present-day), 260 (early Holocene), and $650 \mathrm{ppm}$ (future scenario) using the BIOME4 global vegetation model. Previous experimental studies confirm that vegetation growing on dry and high sites is particularly sensitive to $\mathrm{CO}_{2}$ changes. Here we propose that the replacement of drought-resistant alpine steppes (that are well adapted to low $\mathrm{CO}_{2}$ concentrations) by mesic Kobresia meadows can, at least, be partly interpreted as a response to the increase of $\mathrm{CO}_{2}$ concentration since 7000 years ago due to fertilization and water-saving effects. Our hypothesis is corroborated by former $\mathrm{CO}_{2}$ fertilization experiments performed on various dry grasslands and by the strong recent expansion of high-alpine meadows documented by remote sensing studies in response to recent $\mathrm{CO}_{2}$ increases.
\end{abstract}

(c) 2011 Elsevier Ltd. All rights reserved.

\footnotetext{
* Corresponding author. Alfred Wegener Institute for Polar and Marine Research, Research Unit Potsdam, Germany. Tel.: +49 3317040465.

E-mail address: ulrike.herzschuh@awi.de (U. Herzschuh).
}

\section{Introduction}

Land cover on the Tibetan Plateau strongly affects regional atmospheric circulation (e.g. Yasunari, 2006). Studying its (palaeo)-environmental character is thus essential to understand past and future climatic changes in the Asian monsoonal realm. In this context, the early- to mid-Holocene environmental situation on the Tibetan 
Plateau is of particular interest because, due to globally increasing temperatures, the mid-Holocene may serve as an analogue for the future. A marked feature of the mid-Holocene is the replacement of drought-resistant Artemisia-rich steppes by Kobresia-dominated highalpine meadows as recorded by numerous pollen sequences (Figs. 1 and 2). This vegetation shift has been assumed to reflect a moisture increase (Shen et al., 2008; Herzschuh et al., 2009), although such pollen-based climatic reconstructions contradict the general observation of an weakening Asian summer monsoon during the midHolocene (Fleitmann et al., 2003; Wang et al., 2005). Recently, the midHolocene expansion of Kobresia meadows has been interpreted as a response to the establishment of nomadic herding on the upper Tibetan Plateau (Miehe et al., 2009; Schlütz and Lehmkuhl, 2009).

In glacial times, low atmospheric $\mathrm{CO}_{2}$ concentrations that globally promoted the expansion of drought-resistant vegetation (Polley et al. 1993; Prentice and Harrison, 2009), are also assumed to have affected Tibetan vegetation (Herzschuh et al., 2010a). Inverse vegetation modelling for Africa, however, indicates that Holocene vegetation, in contrast to glacial vegetation, was not sensitive to $\mathrm{CO}_{2}$ variations because either $\mathrm{CO}_{2}$ concentrations already exceeded a critical threshold value or they were too small (Wu et al., 2007). Likewise, changing $\mathrm{CO}_{2}$ concentrations have not previously been considered to be a driving force for Holocene Tibetan vegetation change. However, experimental $\mathrm{CO}_{2}$ fertilization of dry grassland and desert vegetation performed in several regions world-wide has stimulated plant growth directly through enhanced photosynthesis and indirectly through enhanced water-use efficiency (Morgan et al., 2004).

Palaeovegetational investigations that include pollen-based quantitative moisture-balance reconstructions concentrate on Koucha Lake (north-eastern Tibetan Plateau, Herzschuh et al., 2009) and Xuguo Lake (Xuguo Lake, central Tibetan Plateau, Shen, 2003). Both medium-sized lakes have a regional-scale relevant pollen-source area and are situated in the transition zone between Kobresia-meadows and alpine steppe and are thus ideal for tracing vegetational transitions at a regional scale. Furthermore, we provide preliminary results of vegetation modelling using the BIOME4 model that test the sensitivity of Tibetan vegetation to atmospheric $\mathrm{CO}_{2}$ changes. In the discussion, we critically review possible driving forces for early- to mid-Holocene vegetation shifts on the upper Tibetan Plateau (including precipitation, growing season length, radiation, human impact) with particular emphasis on changing $\mathrm{CO}_{2}$ concentrations to better predict future environmental change and impacts on the Tibetan Plateau in a rapidly changing world.

\section{Regional setting}

The climate of the Tibetan Plateau is dominated by the Asian monsoonal circulation. There is a general gradient from high summer temperature (up to $19^{\circ} \mathrm{C}$ ) and high precipitation $(>700 \mathrm{~mm}$ ) on the south-eastern Plateau to low precipitation $(<100 \mathrm{~mm})$ and low summer temperature $\left(\sim 6^{\circ} \mathrm{C}\right)$ on the north-western Tibetan Plateau.

Montane conifer and mixed forests grow in the warm and wet southern, south-eastern, and eastern margins of the Tibetan Plateau up to $\sim 3000 \mathrm{~m}$ in the north and $\sim 4000 \mathrm{~m}$ in the south (Fig. 3 ). Due to intensive logging, forest patches only persist in remote areas and on steep slopes. The north-eastern, northern, central, and western Tibetan Plateau is covered by non-forest vegetation (Hou, 2001). Cold and wet areas on the eastern Tibetan Plateau above $4500 \mathrm{~m}$ support high-alpine meadows mainly composed of different Kobresia species (e.g. Kobresia pygmaea, Kobresia capillifolia). Ranunculaceae, Polygonum, Fabaceae, and Caryophyllaceae are common in these vegetation types which grade into alpine steppe - a mixture of Artemisia, Cyperaceae (e.g. Kobresia littledalei, Kobresia royleana, Carex moorcroftii), and Poaceae (Stipa subsessiliflora, Stipa purpurea) in areas with less than $350 \mathrm{~mm}$ annual precipitation. This steppe vegetation type dominates large areas of the north-eastern and central-western Tibetan Plateau. Only the dry north-central and westernmost regions of the Plateau are occupied by alpine desert steppes, where the dominant Chenopodiaceae (e.g. Ceratoides compacta) are accompanied by Artemisia, Poaceae, Ephedra, and Nitraria. Most areas of the Plateau are regularly grazed, especially the eastern, southern, and central parts.

Koucha Lake $\left(34.0^{\circ} \mathrm{N} ; 97.2^{\circ} \mathrm{E} ; 4540 \mathrm{~m}\right.$ a.s.l.) is situated on the north-eastern Tibetan Plateau (Fig. 1). This freshwater lake $\left(18 \mathrm{~km}^{2}\right.$ area) has a maximum depth of $\sim 6 \mathrm{~m}$. Mean annual precipitation and

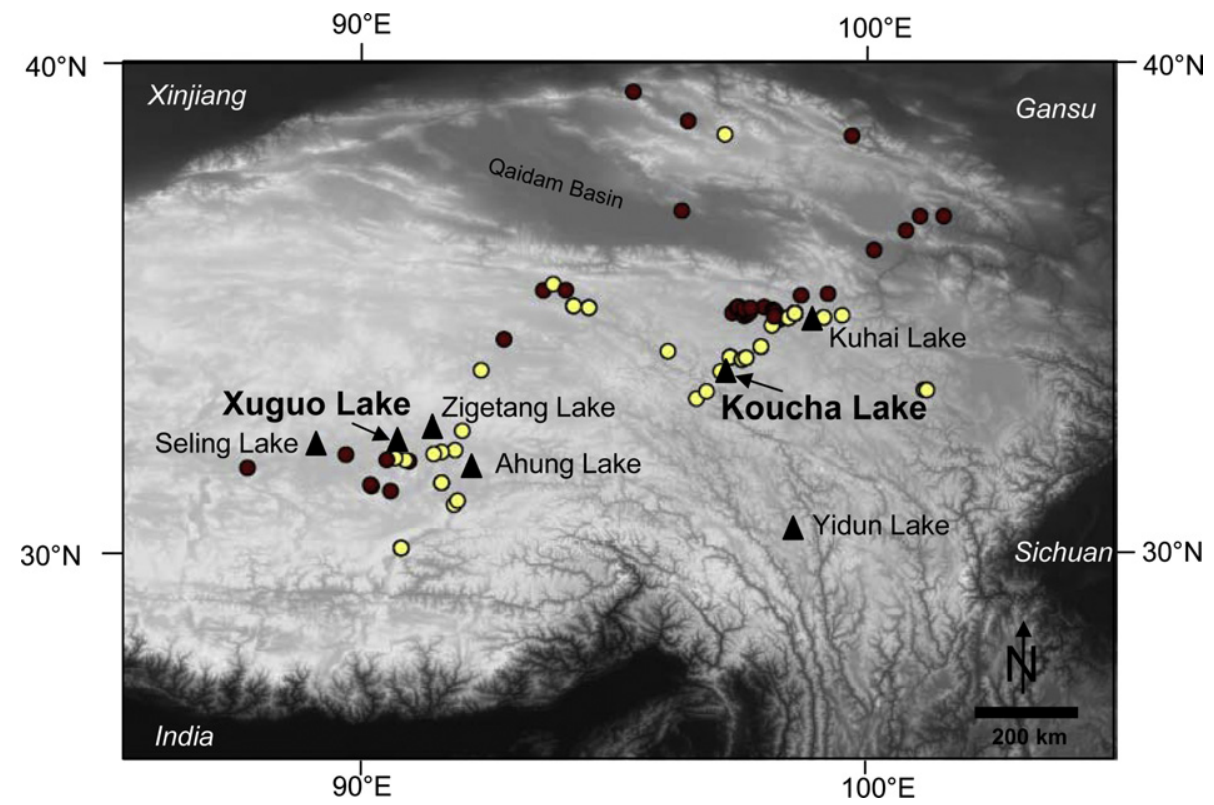

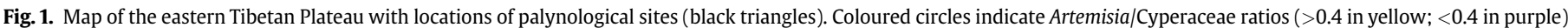

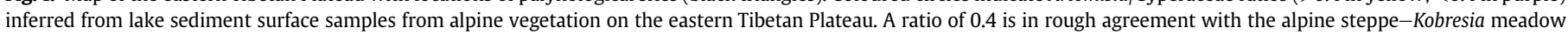
borderline according to Hou (2001). (For interpretation of the references to colour in this figure legend, the reader is referred to the web version of this article.) 

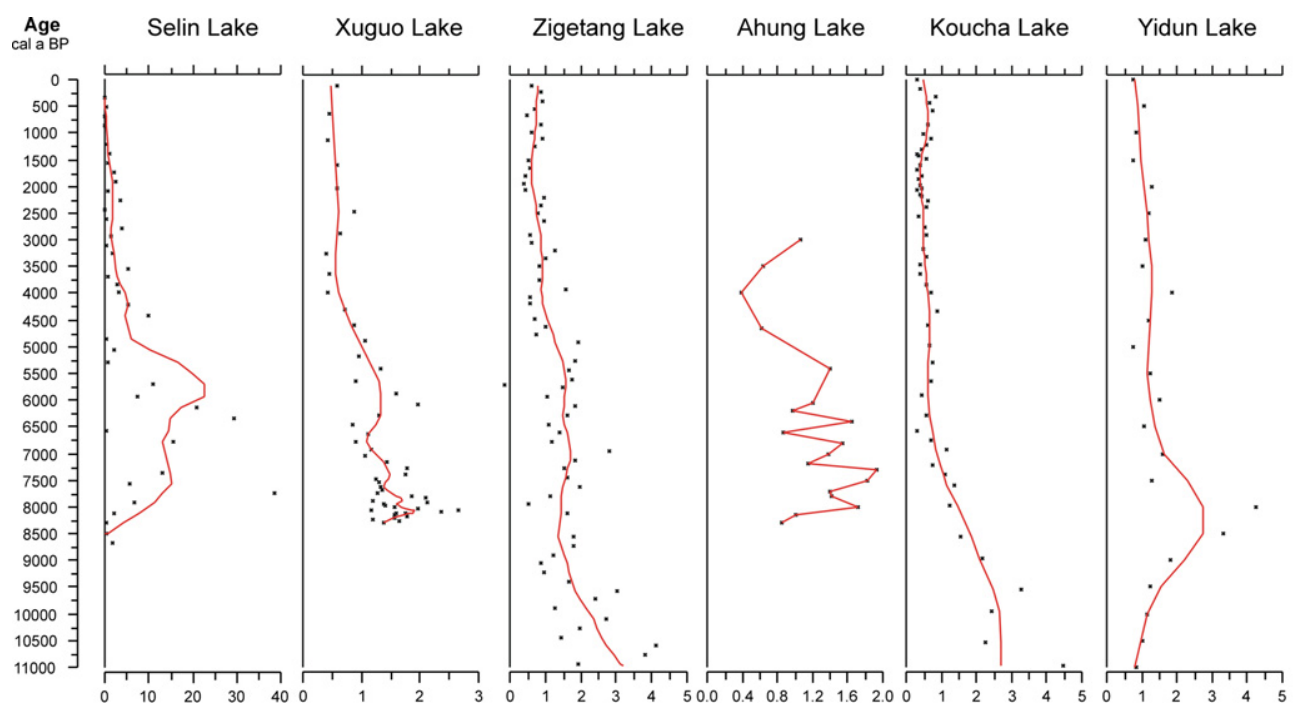

Kuhai Lake

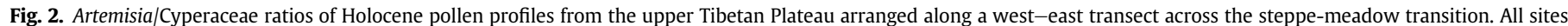

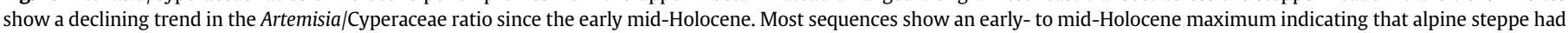

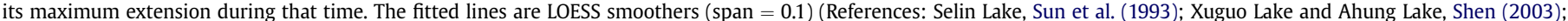
Zigetang, Herzschuh et al. (2006a); Koucha Lake, Herzschuh et al. (2009); Yidun Lake, Shen et al. (2006); Kuhai Lake, Wischnewski et al. (2011)).

mean annual temperature as inferred from the Chengduo climate station $\left(33.8^{\circ} \mathrm{N} ; 97.13^{\circ} \mathrm{E} ; 4418 \mathrm{~m}\right.$ a.s.l.) are $469 \mathrm{~mm}$ and $-4.4^{\circ} \mathrm{C}$, with a modern moisture balance of about -300 to $-400 \mathrm{~mm}$. The immediate vicinity of Koucha Lake is covered by high-alpine Kobresia meadows, whereas the lower plains are covered by alpine steppe (Herzschuh et al., 2009).

Xuguo Lake $\left(31.97^{\circ} \mathrm{N} ; 90.3^{\circ} \mathrm{E} ; 4595 \mathrm{~m}\right.$ a.s.l. $)$ is situated on the central Tibetan Plateau. This brackish-water lake $\left(23 \mathrm{~km}^{2}\right.$ area $)$ has a maximum depth of $\sim 3.5 \mathrm{~m}$. Mean annual precipitation and mean annual temperature as inferred from the Bange climate station $\left(31.38^{\circ} \mathrm{N} ; 90.02^{\circ} \mathrm{E} ; 4701 \mathrm{~m}\right.$ a.s.l.) are $323 \mathrm{~mm}$ and $-0.4^{\circ} \mathrm{C}$, respectively, with a moisture balance of about -400 to $-500 \mathrm{~mm}$. Xuguo
Lake is situated in the transition between Kobresia-dominated meadows and Stipa-Artemisia steppes (Hou, 2001).

\section{Methods}

To obtain a quantitative estimate of Holocene moisture-balance changes from the upper Tibetan Plateau, we developed a pollen-based transfer function using the modern pollen data-set presented in Herzschuh et al. (2010a) and modern moisture-balance data from Böhner (2005). The transfer functions were applied to two fossil datasets; 1) Koucha Lake (original pollen data in Herzschuh et al., 2009) and 2) Xuguo Lake (digitized data from Shen, 2003).

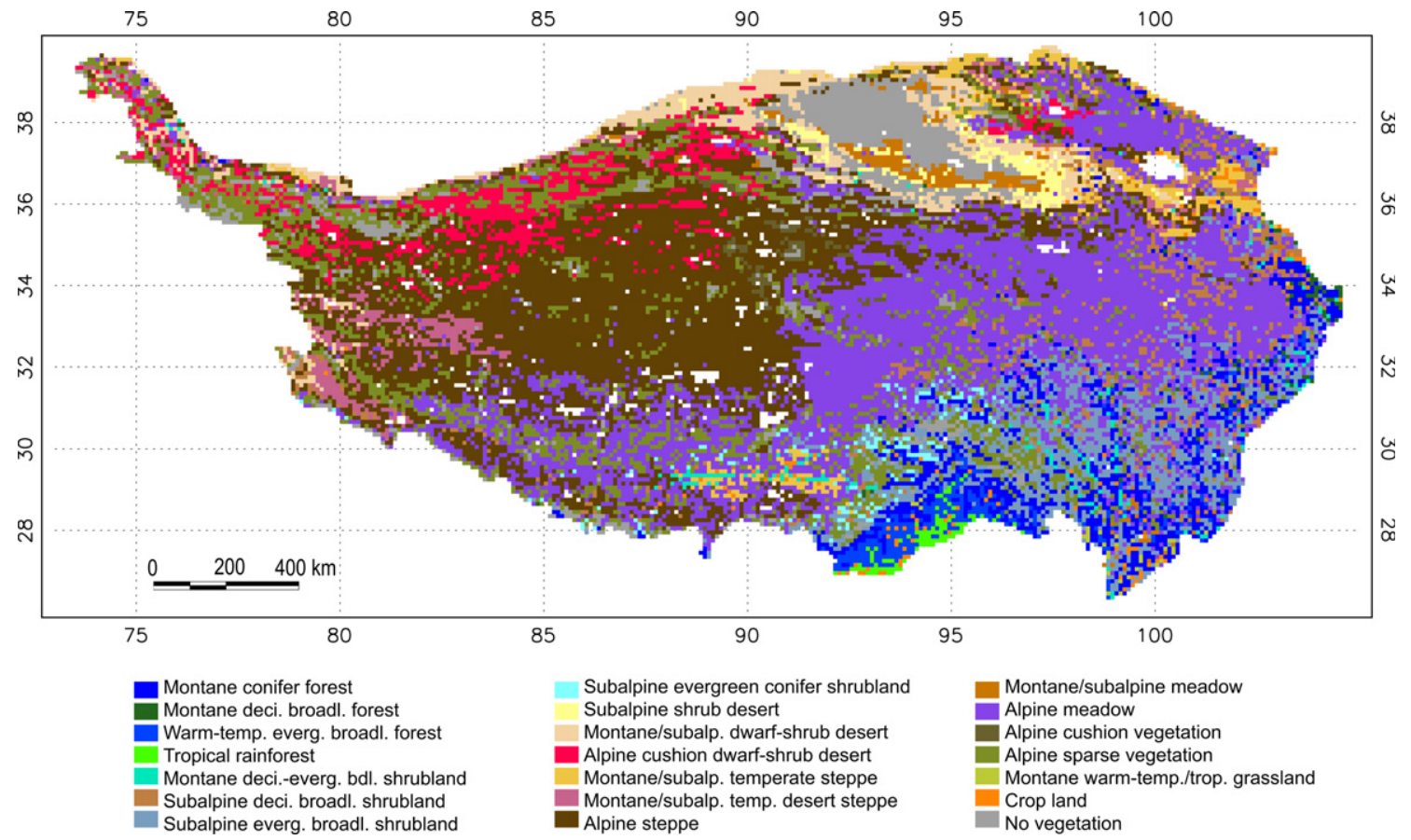

Fig. 3. Vegetation map of the Tibetan Plateau on a $10 \mathrm{~km}$ resolution. Map information obtained from the Vegetation Atlas of China (Hou, 2001). 
To estimate quantitatively the annual moisture-balance (=annual precipitation - annual potential evapotranspiration), we developed a modern pollen-climate calibration data-set based on 132 lake surface-sediments from the eastern Tibetan Plateau, covering a wide moisture-balance range $(-1287$ to $+1008 \mathrm{~mm})$. The original modern pollen data are presented in Herzschuh et al. (2009, 2010a), Zhao and Herzschuh (2009), and Kramer et al. (2010a). Site-specific climate information on moisture-balance was obtained from Böhner (2006). Monthly resolution climate estimates (precipitation, temperature, radiation, evapotranspiration) where performed on a regular grid network ( $3500 \times 4000$ grid cells) covering the whole of Central and High Asia with a grid-cell spacing of $1 \mathrm{~km}^{2}$ (Böhner, 2006). The statistical downscaling approach at the core of geospatial climate modelling integrates gridded circulation variables (GCM data, reanalysis series), available station observations (climate records from more than 400 climate stations) and advanced terrain parameterization methods (Böhner and Antonic, 2008) to account for the topoclimatic heterogeneity of Central Asia. A detailed description of the methods used is given in Böhner (2005).

Pollen and spore percentages were transformed to square roots to stabilise variances prior to further computations. Quantitative transfer functions were developed using weighted averaging partial least-squares regression (WA-PLS), one of the most robust techniques for transfer-function development (Birks, 1998). The number of WA-PLS components included was selected as the number producing the lowest root mean square error of prediction (RMSEP), as estimated by leave-one-out cross-validation (ter Braak and Juggins, 1993), along with a high coefficient of determination $\left(r^{2}\right)$ between observed and predicted values, a low maximum bias, and the smallest number of useful components indicated by a decrease of at least 5\% in RMSEP toward the lower component number (Birks, 1998). WA-PLS was implemented in C2 1.3 (Juggins, 2003).

We improved the global vegetation model BIOME4 (a coupled biogeographical and biogeochemical including carbon and waterflux model; Kaplan et al., 2003; Song et al. 2005) by re-parameterizing some bioclimatic factors of key plant functional types on the Tibetan Plateau (Ni and Herzschuh, in press). Biomes on the Tibetan Plateau were then simulated with different $\mathrm{CO}_{2}$ concentrations 375 (present-day), 260 (early Holocene), and $650 \mathrm{ppm}$ (future scenario) - using the improved BIOME4-Tibet model driven by present-day climate and soil data, Monthly mean temperature, precipitation and sunshine percentages, and minimum temperature were interpolated to $10^{\prime}$ resolution from the 1971 to 2000 averaged meteorological records from 1814 weather stations across China. The soil properties of water-holding capacity and percolation rate were derived from the FAO digital global soil map (FAO, 1995; Kaplan et al., 2003).

The simulation using BIOME4-Tibet (Ni and Herzschuh, in press) has proved that modern biome distribution is in general agreement with the potential natural vegetation. Due to the limited number of vegetation types included in BIOME4, the model cannot differentiate between alpine shrub vegetation and high-alpine Kobresia meadows. However, the model initially determines leaf area index (LAI) to infer net primary productivity (NPP) for each given PFT and uses this information together with the climate data to predict biomes. To explore the effects of $\mathrm{CO}_{2}$ changes we therefore investigated the changes and percentage changes of NPP.

\section{Results}

\subsection{Pollen-based reconstructions}

Holocene changes in the Artemisia/Cyperaceae (A/Cy) ratio for several pollen records arranged along a gradient from dry to wet sites today are shown in Fig. 2, giving a rough estimate of alpine

\section{Table 1}

Model performance statistics as assessed by leave-one-out cross-validation of the first three components of the WA-PLS pollen-based moisture-balance transfer functions in terms of RMSEP - root mean square error of prediction $(\mathrm{mm}), r^{2}-$ coefficient of determination between predicted and observed climate values, maximum (max.) bias ( $\mathrm{mm}$ ) and percentage change in RMSEP toward the lower component model. The selected model is shown in bold.

\begin{tabular}{llllc}
\hline No. of components & RMSEP & $r^{2}$ & Max. bias & \% change \\
\hline 1 & 190 & 0.81 & 367 & - \\
$\mathbf{2}$ & $\mathbf{1 7 7}$ & $\mathbf{0 . 8 3}$ & $\mathbf{2 5 0}$ & $\mathbf{6 . 8 \%}$ \\
3 & 180 & 0.82 & 265 & $-1.6 \%$ \\
\hline
\end{tabular}

steppe to meadow variations. The A/Cy values are relatively higher at the dry western sites and lower at the moist eastern sites, a picture that is also seen from modern lake-sediment pollen spectra from the upper eastern Tibetan Plateau (Fig. 1). All fossil pollen records show a significant decrease in the $\mathrm{A} / \mathrm{Cy}$ ratio by the mid-Holocene due to the widespread expansion of Kobresia meadows, especially on the central (Silin Lake, Xuguo Lake) and north-eastern Tibetan Plateau (Koucha Lake).

To estimate what moisture changes these vegetation shifts might reflect, we developed a modern pollen-based moisture-balance transfer function. A two-component WA-PLS model was chosen to be the most parsimonious model on the basis of the model performance statistics (Table 1). Root mean square error of prediction (RMSEP) is $177 \mathrm{~mm}$, coefficient of determination $\left(r^{2}\right)$ is 0.83 between observed and model-predicted values of moisture-balance, and maximum bias is $250 \mathrm{~mm}$. RMSEP, when expressed as a percentage of the gradient, is $6.8 \%$, illustrating the very good performance of the model. Plots of predicted moisture-balance against observed moisture-balance (Fig. 4) and of the residuals against the observed moisture-balance illustrate the robustness of the model over the modern annual moisture-balance range from -1287 to $+1008 \mathrm{~mm}$. The plots also indicate that biases are mostly below average for sites with -600 to $-400 \mathrm{~mm}$ of annual moisture-balance found on the north-eastern and central Tibetan Plateau.

Pollen-based annual moisture-balance inferences (Fig. 5) for Xuguo Lake yield values around $-480 \mathrm{~mm}$ until ca $6 \mathrm{ka}$ BP followed by an steady increase to $\sim-300 \mathrm{~mm}$ reached by $3 \mathrm{kaBP}$. The moisture-balance reconstruction for Koucha Lake generally shows considerable variability. A slight decreasing trend from $\sim-400$ to $-500 \mathrm{~mm}$ is found between 11 and $8 \mathrm{ka} \mathrm{BP}$, followed by a moisture increase to $\sim 350 \mathrm{~mm}$ towards the late-Holocene.

\subsection{Sensitivity of net primary productivity and biomes to atmospheric $\mathrm{CO}_{2}$ concentrations}

The trends of the BIOME4 model-based NPP prediction for present-day $\mathrm{CO}_{2}$ levels (375 ppm; Fig. 6) are in good agreement with modern remote-sensing based observations (Piao et al., 2006), i.e. a decrease in NPP from the south-east to north-west. However, the absolute values on the upper Tibetan Plateau, are slightly higher (by $\sim 50-100 \mathrm{gC} / \mathrm{m}^{2} / \mathrm{a}$ ) in the model than in the observations, especially in the north-western part. The model-based $\mathrm{CO}_{2}$ effects on NPP distribution (Fig. 7) are distinct all over the Plateau both for $\mathrm{CO}_{2}$ lowering from modern to early-Holocene levels (375-260 ppm) and for an increase from modern values to a future scenario (375-650 ppm). NPP is reduced at $260 \mathrm{ppm}$ by $>120 \mathrm{gC} / \mathrm{m}^{2} / \mathrm{a}$ at moist alpine sites on the south-eastern Plateau, by $\sim 80 \mathrm{gC} / \mathrm{m}^{2} / \mathrm{a}$ in the transition area on the central Tibetan Plateau, and by $30 \mathrm{gC} / \mathrm{m}^{2}$ / a on the north-western Plateau, which indicates a reduction by $\sim 25 \%$. In the desert area of the Qaidam Basin, and on the northwestern Tibetan margin it is lowered by $20 \mathrm{gC} / \mathrm{m}^{2} / \mathrm{a}$ and by $60 \mathrm{gC} /$ $\mathrm{m}^{2} / \mathrm{a}$ in the surrounding temperate steppe and xerophytic 

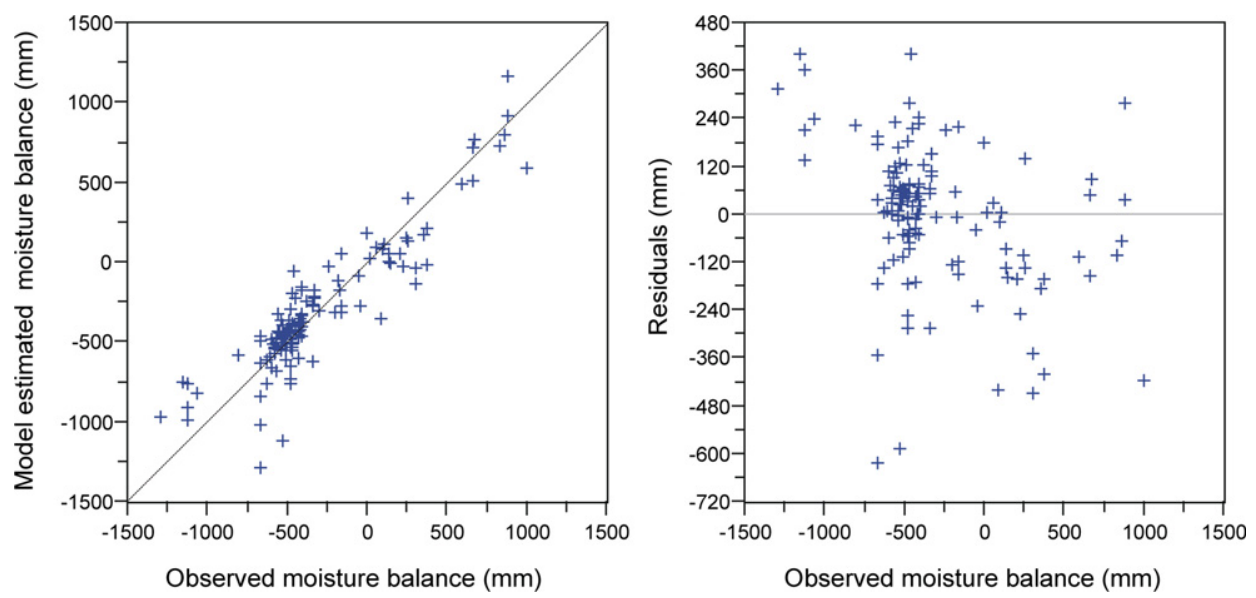

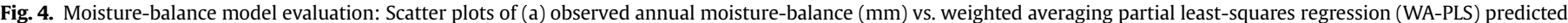

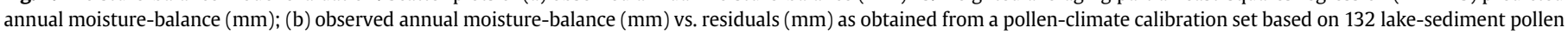
spectra from the Tibetan Plateau.

shrubland, which indicates a NPP reduction of 30-40\%. In contrast, positive NPP changes of $30-45 \%$ are predicted when $\mathrm{CO}_{2}$ changes from $375 \mathrm{ppm}$ to $650 \mathrm{ppm} \mathrm{CO}_{2}$. The NPP in the desert area of the Qaidam Basin almost doubles.

The model-based $\mathrm{CO}_{2}$ effects on biome distribution on the Tibetan Plateau are rather limited (supplementary online material Fig. a and b). A shift to dry vegetation occurs when $\mathrm{CO}_{2}$ is changed from present-day ( $375 \mathrm{ppm}$ ) to early-Holocene conditions ( $260 \mathrm{ppm}$ ) with temperate conifer forest, cold mixed forest, and evergreen taiga changing to non-forest in the south, and grassland to shrubland, shrub tundra to steppe tundra, and shrubland to desert and grassland in the north-east and south-east. A trend to more mesic vegetation is found under higher $\mathrm{CO}_{2}(650 \mathrm{ppm})$ with grassland and shrub tundra changing to conifer and mixed forests in the south, and desert, grassland, and shrubland changing to shrub tundra, and shrubland changing to desert and grassland in the east.

\section{Discussion}

\subsection{Climatic changes are unlikely as the vegetation driver}

In most palaeoecological studies from Central Asia it is assumed that climate is the dominant forcing parameter for Holocene vegetation change. Here we examine how several climate parameters could have changed to cause the observed vegetation patterns and how the inferred climatic change fits to earlier non-pollen climate

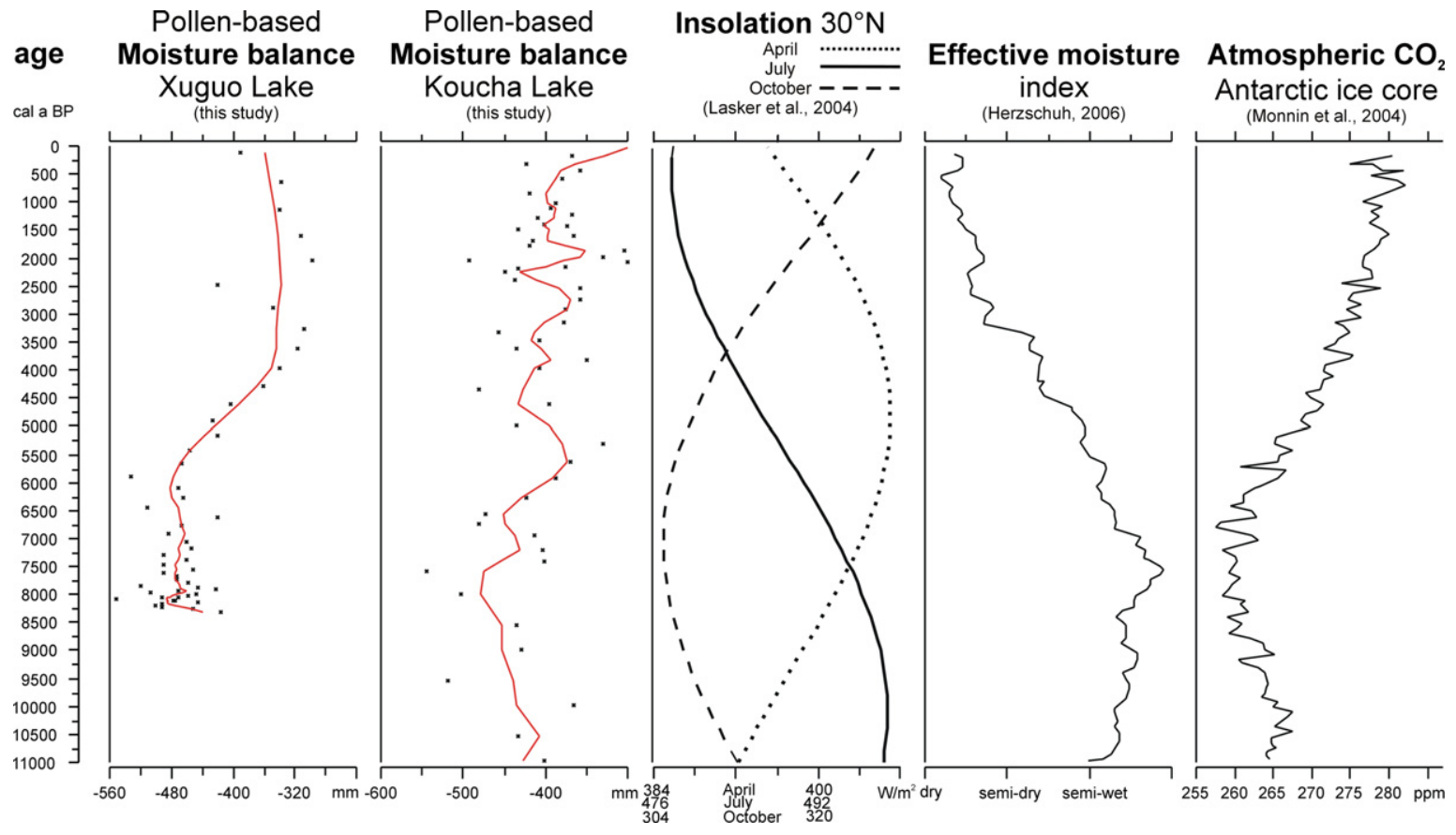

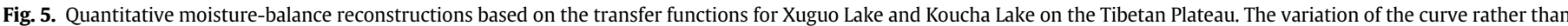

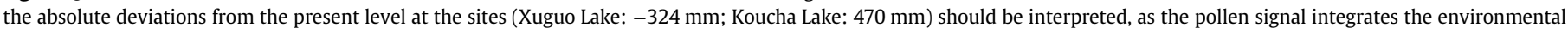

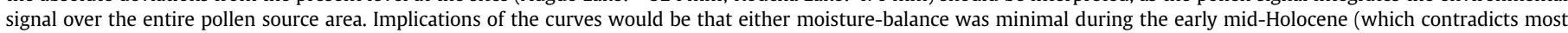

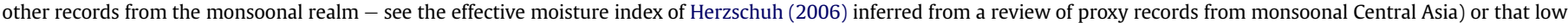

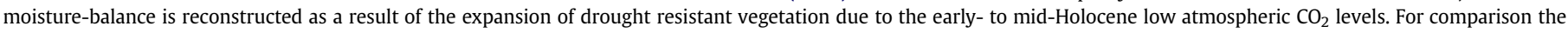
Antarctic ice-core $\mathrm{CO}_{2}$ data and calculated insolation at $30^{\circ} \mathrm{N}$ for the Holocene are shown. 


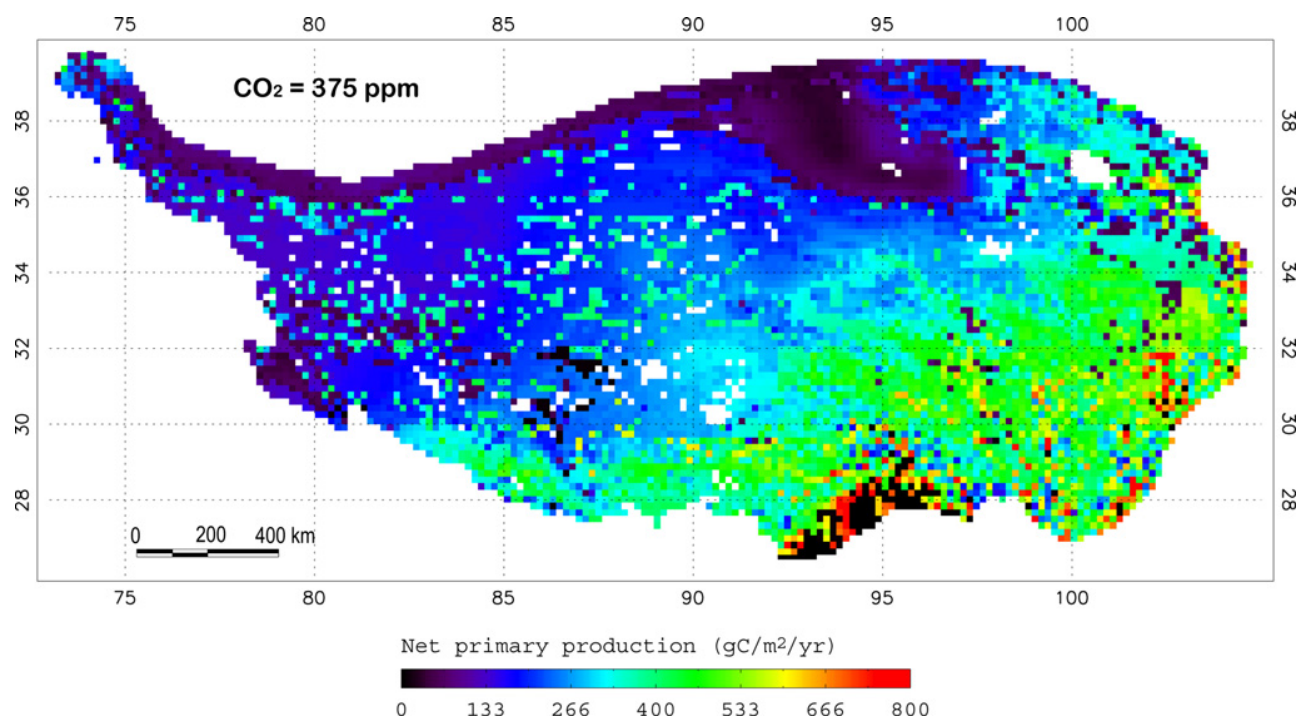

Fig. 6. Distribution of net primary productivity on the Tibetan Plateau as predicted by the BIOME4 vegetation model for current atmospheric $\mathrm{CO}_{2}$ concentration $(375 \mathrm{ppm})$.

reconstructions from monsoonal Asia. Plant-available moisture is the decisive parameter for vegetation distribution and productivity on the upper Tibetan Plateau (Fu et al., 2009; Yang et al., 2009). Characteristic elements of early-Holocene steppes (Artemisia, Ephedra) that today dominate the relatively dry north-eastern and north-central Plateau, are well adapted to water limitation as indicated by their high water-use efficiency (i.e. the ratio of carbon gained to water lost in leaf gas exchange), morphology, and chemical leaf traits compared to mesic Kobresia-meadows that today occupy comparatively mesic areas on the eastern and southern Plateau (Pyankov and Kondrachuk, 2003; Song et al., 2008). Quantitative moisture-balance reconstructions from Koucha Lake and Xuguo Lake (Fig. 5) have a Holocene minimum of $200 \mathrm{~mm}$ below presentday conditions during the early mid-Holocene and an increasing moisture-balance trend thereafter. Hence, pollen-inferred moisture changes from the Kobresia meadow-alpine steppe transition area on a
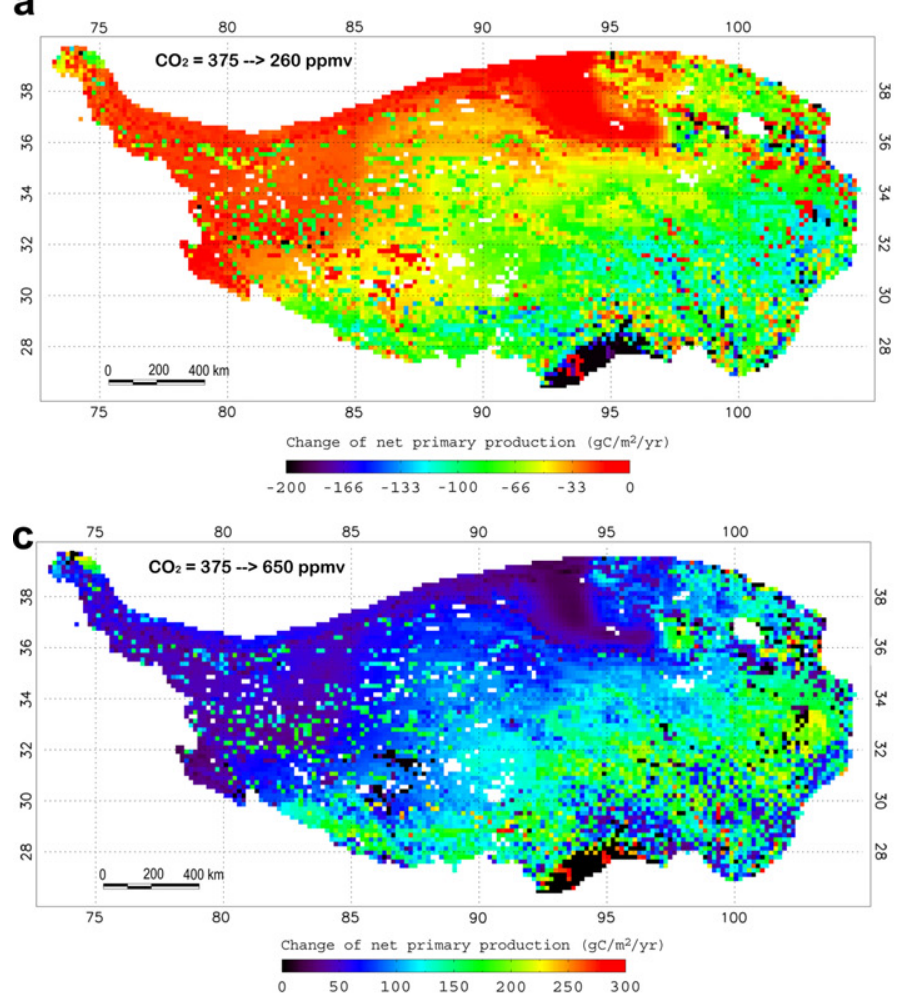

b
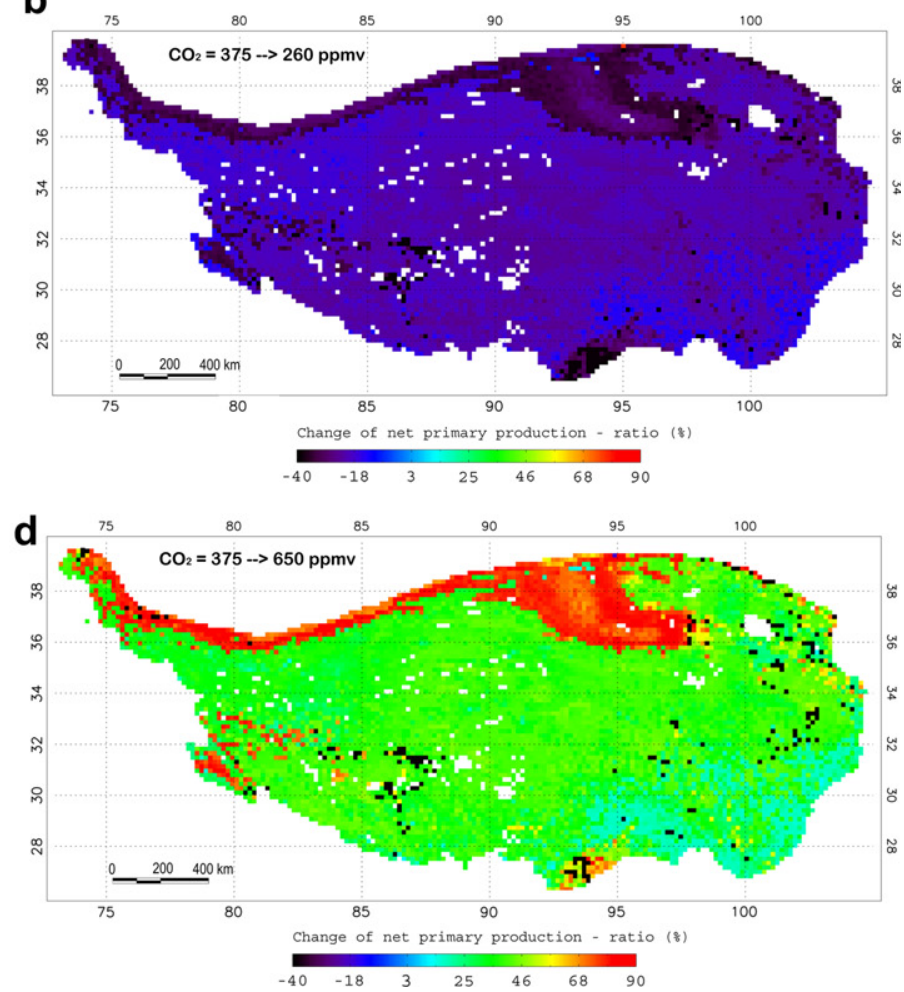

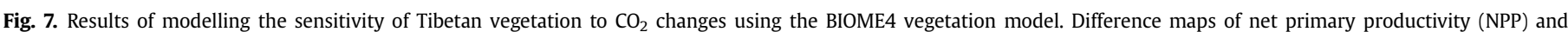

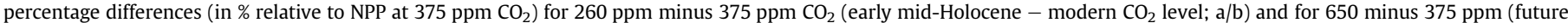

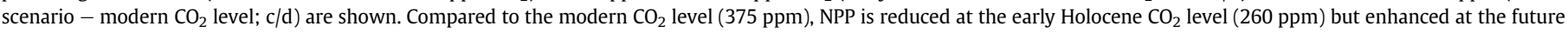
scenario level (650 ppm). 
the upper Tibetan Plateau are in marked contrast to most nonvegetation records from the Tibetan Plateau that indicate a wet first half of the Holocene and a drying trend thereafter, being in line with other high-resolution proxy records from the monsoonal realm and with modelling results (e.g. Zhao et al., 2005; Herzschuh, 2006). Declining moisture is generally interpreted as a response to monsoonal weakening as a result of low-latitude summer insolation decrease. However, vegetation records from rather moist marginal areas at lower altitudes on the Tibetan Plateau (Shen et al., 2005; Herzschuh et al., 2006a; Kramer et al., 2010a) are in line with this general trend. The continuous decline of forest since 6 cal ka BP can be most reasonably explained by a precipitation and/or temperature reduction (Herzschuh et al., 2010c).

Beside precipitation, changing seasonality may have impacted Holocene vegetation on the upper Tibetan Plateau. The annual growing season today extends from May to September and is mainly a function of air temperature (Fu et al., 2009). The total amount of annual insolation was higher during the early-Holocene compared with today. This was proposed to have resulted in the upward shift of temperate steppe-meadow vegetation in continental Asia (Herzschuh et al., 2006b). The insolation sum of the growing season-boundary months, April and October, however, was slightly lower than today during the early-Holocene (Laskar et al., 2004; Fig. 5), indicating that the length of the growing season was not longer. Due to low winter insolation, the soil probably required even more time to thaw in spring and this may have shortened the growing season further.

Field and laboratory investigations on Tibetan alpine vegetation show that carbon gain and biomass production are limited in time by high light intensities, and that the limitation is even exacerbated by high leaf temperature and water stress (Cui et al., 2004). Due to photo-inhibition, a $5 \%$ loss in gross primary productivity is modelled for present-day Kobresia meadows (Zhang and Tang, 2005). Under clear sky conditions, early-Holocene summer radiation would have been higher than today as a result of higher summer insolation (Fig. 5). However, the influences of radiation on primary productivity of Tibetan vegetation (e.g. reduction of wateruse efficiency under strong radiation) are largely dependent on cloudiness (Gu et al., 2003) which is difficult to reconstruct. Greater early- and mid-Holocene cloudiness as a result of an enhanced Indian summer monsoon is modelled by Liu et al. (2004) and Zhao et al. (2005), and is assumed to be a result of high cosmogenic ray fluxes (linked to the earth`s magnetic field) by Knudsen and Riisager (2009). However, whether these effects compensate for the stronger insolation, especially in largely cloud-free areas of the central Tibetan Plateau, is unlikely because neither of the described radiation/cloudiness effects could reasonably explain the relatively high effective moisture at the very beginning of the Holocene compared to the mid-Holocene.

To conclude, precipitation changes and changes in seasonality probably do not account for the wide expansion of steppe vegetation during the early- or mid-Holocene. Variations of Holocene radiation effects on vegetation are still largely unknown.

\subsection{Holocene land-use changes unrelated to expansion of Kobresia meadows}

Miehe et al. (2009) hypothesised that the present-day Kobresiadominated high-alpine meadows as a whole represent largely an artificial vegetation complex resulting from anthropogenic landuse practices reaching back to $8.8 \mathrm{cal} \mathrm{kaBP}$. In support of this hypothesis, there is growing evidence from different marginal areas of the Tibetan Plateau that herding of domesticated yak started sometime during the early- or mid-Holocene (Guo et al., 2006; Dearing et al., 2008; Meyer et al., 2009). However, wide-spread, intensive, and persistent human land-use is not documented by archaeological evidence: although there exists a number of latePleistocene sites, only one archaeological site (Xidatan 2 from the Kunlun Mountains at the northernmost Plateau margin) of EpiPalaeolithic culture has been found on the upper $(>3500 \mathrm{~m})$ Tibetan Plateau from 11 to 3.7 ka BP (Aldenderfer and Zhang, 2004; Brantingham and Gao, 2006; Brantingham et al., 2007). Chugong (5 km north of Lhasa, $3680 \mathrm{~m}$ a.s.l.), is the only Neolithic site in the present-day Kobresia meadow or alpine steppe area that provides evidence for year-round occupation on the upper Plateau. It is dated to $\sim 3.7 \mathrm{cal} \mathrm{ka} \mathrm{BP}$ (Aldenderfer, 2007). This observation is roughly in line with the marked increases of grazing indicators by $3.4 \mathrm{cal}$ ka BP in a lake pollen record from the south-eastern Tibetan Plateau (Kramer et al., 2010a) and with increases of grazing indicators by $2.2 \mathrm{cal} \mathrm{ka} \mathrm{BP}$ in a peat record from the eastern Tibetan Plateau (Schlütz and Lehmkuhl, 2009). The differentiation between natural-zoogenic and anthropo-zoogenic grazing from pollen records remains very problematic (Miehe et al., 2009), especially when interpreting the very local palynological information from peat and soil sequences. Such very local sequences are inappropriate archives of regional grazing intensity (Jacobson, 1988). Modern vegetation studies involving exclosure experiments (Miehe et al., 2008; Wu et al., 2009), show that (1) fencing promotes the expansion of Poaceae, (2) Kobresia is still the dominant element of ungrazed meadows, and (3) Artemisia is favoured rather than replaced by grazing. This is in clear contrast to the fossil pollen record as (1) Poaceae shows no trend during the Holocene in regional pollen records (e.g. Zigetang Lake, Herzschuh et al., 2006b; Koucha Lake, Herzschuh et al., 2009); (2) Artemisia declines, and (3) Kobresia expands after the onset of proposed anthropo-zoogenic grazing. Evidence for Kobresia meadows being a natural element on the Tibetan Plateau is indicated by $>80 \%$ Cyperaceae in lake pollen assemblages of Lateglacial (Allerød) age, indicating the widespread occurrence of Kobresia meadows on the south-eastern and northeastern Tibetan Plateau under cool and wet climate conditions (Herzschuh et al., 2006a; Kramer et al., 2010b). Still, due to the impossibility of differentiating Kobresia pollen morphologically from other Cyperaceae we cannot be absolutely sure that it was Kobresia that expanded during the Lateglacial. However, the composition of the Lateglacial high-alpine meadow at Naleng Lake e.g. the co-occurrence of Polygonum bistorta-type and Swertia (Kramer et al., 2010b) is very similar to modern Kobresia meadow pollen assemblages.

To conclude, the extent and timing of anthropogenic land-use on the upper Tibetan Plateau and its possible impacts on high alpine vegetation are still mostly unknown. However, it is unlikely that modern Kobresia meadows are mainly of artificial origin.

\subsection{Changes in atmospheric $\mathrm{CO}_{2}$ concentration as the driving force of vegetation change}

Partial $\mathrm{CO}_{2}$ pressure decreases strongly with altitude while the molar $\mathrm{CO}_{2}$ concentration in air remains constant. Earlier plant physiological modelling studies concluded that the pressure reduction is largely mitigated by physical mechanisms such as faster molecular gas diffusion and parallel lowered $\mathrm{O}_{2}$, which competes with $\mathrm{CO}_{2}$ at the Rubisco reaction site (Terashima et al., 1995). However, experimental investigations have shown that the photosynthetic capacity of upland population increases to the same extent as the partial $\mathrm{CO}_{2}$ pressure is artificially raised (Körner and Diemer, 1987; Bresson et al., 2009). Transferred to the central Tibetan Plateau $(\sim 4500 \mathrm{~m})$, this finding implies that alpine vegetation suffers from $40 \%$ lower carbon availability compared to sealevel. However, the photosynthetic capacity of alpine plants is not correspondingly lowered, probably as a result of physiological 
adaptation and acclimation, thereby accepting higher energetic costs to compensate for the low efficiency of physiological processes at high altitudes (Reich and Oleksyn, 2004). High-alpine plants have high leaf nitrogen concentrations indicating lower plant nitrogen-use efficiency (for the Tibetan Plateau, see He et al., 2006) and low water-use efficiency (Körner et al., 1988; for Tibetan Plateau, see Wei and Jia, 2009). Thus plants with xeromorphic leaf anatomies such as increased stomatal densities (Pyankov and Kondrachuk, 2003) are at a competitive advantage. Hence, the central physiological adaptations to dry ecosystems and to high altitudes (i.e. low leaf nitrogen-use efficiency and high water-use efficiency) are similar and such adaptations are demonstrated in gradient studies of Tibetan vegetation (He et al., 2006; Wei and Jia, 2009). Experimental and modelling investigations have shown that plant-growth response to elevated $\mathrm{CO}_{2}$ concentrations is amplified in vegetation types with high nitrogen but limited water supply (Nowak et al., 2004; McMurtrie et al., 2008). Hence, Tibetan vegetation composition, especially on comparatively high and dry sites, might be especially sensitive to lowering of $\mathrm{CO}_{2}$ concentration as the adaptive capacity of single plant taxa may then be exceeded.

According to Antarctic ice-core records (Indermühle et al., 1999; Monnin et al., 2004), Holocene $\mathrm{CO}_{2}$ concentrations were comparatively high between 11 and $10 \mathrm{ka}$, decreased during the earlyHolocene, showed a minimum at less than 260 ppm around 7000 a, increased afterwards to pre-industrial levels of $285 \mathrm{ppm}$ (Fig. 5), and then increased to present-day values of $\sim 375 \mathrm{ppm}$ that are markedly above early- or mid-Holocene conditions. Hence, minimum $\mathrm{CO}_{2}$ concentrations correlate with the maximum expansion of low-biomass and drought-resistant alpine steppe vegetation on the Tibetan Plateau. Furthermore, our $\mathrm{CO}_{2}$ sensitivity studies confirm that a $\mathrm{CO}_{2}$ increase from early-Holocene to presentday levels strongly enhances NPP on the Tibetan Plateau, reducing the expansion of low-biomass and drought-resistant vegetation.

Even though the trends of vegetation-inferred moisture-balance parallel $\mathrm{CO}_{2}$ concentration changes well and vegetation modelling results confirm that the lowering of $\mathrm{CO}_{2}$ concentration to earlyHolocene levels markedly reduces the NPP of Tibetan vegetation, four questions remain open that need to be answered before $\mathrm{CO}_{2}$ concentrations can be proposed as a main driving force for Holocene vegetation change:

(1) Do modern $\mathrm{CO}_{2}$ fertilization experiments indicate that waterlimited alpine vegetation, such as Tibetan steppes and meadows, are especially vulnerable to $\mathrm{CO}_{2}$ concentration changes? $\mathrm{CO}_{2}$ enrichment studies from the Tibetan Plateau or from other high-alpine steppe vegetation are completely lacking. However, there is growing evidence that water-limited grassland vegetation is amongst those vegetation types that show the strongest positive reactions to $\mathrm{CO}_{2}$ enrichment, especially due to reduced water consumption (Nelson et al., 2004; Niklaus and Körner, 2004). The few free-air enrichment studies performed at (water-saturated) alpine sites yielded no amplification of $\mathrm{CO}_{2}$ enrichment due to low $\mathrm{CO}_{2}$ pressure (Körner et al., 1997). However, comparison of $\mathrm{CO}_{2}$ enrichment effects to pairs of a lowland and an upland species yielded a stronger biomass increase for the upland species (Körner and Diemer, 1994; Olivo et al., 2002), indicating that upland vegetation is more vulnerable to $\mathrm{CO}_{2}$ concentration changes.

(2) Can changing $\mathrm{CO}_{2}$ account for species turnover as has been inferred for the mid-Holocene on the Tibetan Plateau? Species shifts in grasslands as a result of $\mathrm{CO}_{2}$ fertilization have been reported by many authors (e.g. Potvin and Vasseur, 1997; Niklaus et al., 2001). A $\mathrm{CO}_{2}$ enrichment experiment on dominant species from the North American sagebrush steppe showed that water-use efficiency of grass species (Stipa,
Elymus) increased more strongly than for Artemisia (Lucash et al., 2005). This is in agreement with the review of Ainsworth and Rogers (2007) on the reaction of different plant functional types to $\mathrm{CO}_{2}$ enhancement that suggested that, on average, grasses were twice as strongly stimulated by $\mathrm{CO}_{2}$ enhancement as shrubs. An extensive enrichment study of a calcareous seasonally water-limited grassland dominated by Bromus (Poaceae) and Carex spp. (Cyperaceae) probably represents the best vegetation analogy to alpine Tibetan vegetation (Niklaus and Körner, 2004). This study showed that biomass gains were disproportionately large for mesic Carex species and were mainly indirectly caused through water savings. It was concluded that the increase of soil moisture was the major effect of elevated $\mathrm{CO}_{2}$ and this was translated to various characteristics of the ecosystem. By analogy, the increase of soil moisture as a result of lower water consumption during the early- to mid-Holocene on the Tibetan Plateau may have promoted the expansion of mesic Kobresia at the expense of xeromorphic shrubby Artemisia while the abundance of intermediate Poaceae was unaffected.

(3) Can the absolute values in moisture and biomass change largely be explained by the relatively small pre-industrial Holocene $\mathrm{CO}_{2}$ concentration variations? The global $\mathrm{CO}_{2}$ increase of $25 \mathrm{ppm}$ between 6 and $1 \mathrm{cal} \mathrm{ka}$ BP is paralleled by a leaf-area increase of $\sim 20 \%$ on the Tibetan Plateau (Herzschuh et al., 2010b) assuming a moisture-balance increase by $\sim 30 \%$. Free-air $\mathrm{CO}_{2}$ treatment of a natural $\mathrm{C} 3$ steppe (with a total $\mathrm{CO}_{2}$ gradient between 250 and $550 \mathrm{ppm}$ ) showed a biomass increase of $\sim 20 \%$, a water-use efficiency increase of $\sim 40 \%$, and a soil water content increase of $\sim 15 \%$ for a $\mathrm{CO}_{2}$ concentration increase from 260 to $285 \mathrm{ppm}$ (Fay et al., 2009). These investigations indicate that the Holocene vegetation changes are in the same order of magnitude as experimental results though the latter neglected acclimation and long-term effects (Arp, 1991). Furthermore, our $\mathrm{CO}_{2}$ sensitivity study indicates that NPP is lowered at $260 \mathrm{ppm}$ atmospheric $\mathrm{CO}_{2}$ by as much as $\sim 25 \%$ in the moist tundra-steppe tundra transition zone of the Central Tibetan Plateau compared to present-day $\mathrm{CO}_{2}$ concentrations.

(4) Has the modern global $\mathrm{CO}_{2}$ fertilization affected Tibetan vegetation during recent decades? Sophisticated remote-sensing studies show that increasing biomass in North America is related to the direct fertilization effect of increasing atmospheric $\mathrm{CO}_{2}$ concentration (e.g. Lim et al., 2004). Increases in biomass and NPP during recent decades are also found by several remotesensing studies (partly with ground-truthing) from the Tibetan Plateau but with strong regional differences. Grassland biomass changes are not or only moderately correlated to meteorological variables such as increasing temperature, increasing precipitation, and decreasing evapotranspiration (Chu et al., 2007). NPP prediction of a carbon model driven with NDVI data (Normalised Difference Vegetation Index - a measure of standing biomass) for 1982-1999 indicates that the strongest increase in NPP occurred in high-alpine meadows in the period from 1992 to 1999 (Piao et al., 2006). Furthermore, in an investigation of biomass changes from 1981 to 2001 in the Tibetan Autonomous Region (Zhang et al., 2007a,b), the strongest NDVI increase was found in the transition area from Kobresia to steppe vegetation (roughly $87^{\circ}-93^{\circ} \mathrm{E} ; 30^{\circ}-33^{\circ} \mathrm{N}$, comprising Xuguo Lake area) despite a population density increase of $23 \%$ from 1989 to 2002. The results from all these studies are further indications that the transition from steppe to meadow on the Tibetan Plateau could be partly driven by $\mathrm{CO}_{2}$ concentration changes.

Our results indicate that Holocene $\mathrm{CO}_{2}$ changes should be taken into account when vegetation records are interpreted in terms of 
either climate or land-use changes. However, our study design is not appropriate to draw firm conclusions about the influence of Holocene $\mathrm{CO}_{2}$ variations on Tibetan vegetation change. We have considered the potential of single factors to trigger changes in upper Tibetan Plateau vegetation from a theoretical perspective. Furthermore, we have restricted our investigation to the transition area between alpine steppe and high-alpine meadows and do not extend our hypothesis to other vegetation types. Pollen-based inverse vegetation modelling (Guiot et al., 2008) may help to overcome some of the limitations in our study design. However, for that purpose the vegetation models first need to be adjusted for specific Tibetan vegetation types and probably also for altitudinal effects on photosynthesis and human land-use changes.

\subsection{Implications of a strong $\mathrm{CO}_{2}$ sensitivity of Tibetan vegetation for future global change}

According to this $\mathrm{CO}_{2}$ hypothesis, the expansion of Kobresia was promoted by globally increasing $\mathrm{CO}_{2}$ concentrations from 7000 years ago mainly due to the effects of fertilization and improved water economy. In contrast to the hypothesis of Ruddiman (Ruddiman, 2003; Ruddiman and Ellis, 2009), Elsig et al. (2009) assigned the early-mid Holocene $\mathrm{CO}_{2}$ changes to ocean carbon release but at least the $\mathrm{CO}_{2}$ increase during the last centuries is of anthropogenic origin (Friedli et al., 1986). Independent of the cause of $\mathrm{CO}_{2}$ increase, because of its dryness and probably also due to its high-elevation, the Tibetan Plateau was probably among the first ecosystems that responded to these greenhouse-gas increases. A stabilisation at $650 \mathrm{ppm} \mathrm{CO}_{2}$ concentration after 2100 is one that was investigated in the context of IPCC (2007). Experimental treatment of vegetation with increased $\mathrm{CO}_{2}$ concentration yields higher biomass production in natural water-limited grassland and desert ecosystems (Morgan et al., 2004). Steppe-Kobresia meadow transition areas on the central Tibetan Plateau that are probably most sensitive to $\mathrm{CO}_{2}$ changes, are likely to turn into Kobresia meadows which would act as a carbon sink. Our results from vegetation modelling of the Tibetan Plateau with $650 \mathrm{ppm}$ prescribed $\mathrm{CO}_{2}$ yields a strong increase in NPP all over the Tibetan Plateau (Fig. 7d). The relative increase is particularly high in the desert areas of the Qaidam Basin and in Central Tibet. However, the responses of other global change-related climatic parameters, especially temperature, precipitation, and cloudiness, and changing human impact will almost certainly modify the vegetation response to changing atmospheric $\mathrm{CO}_{2}$ concentrations. An experimental doubling of $\mathrm{CO}_{2}$ at a Kobresia meadow site enhanced the apparent quantum-use efficiency of vegetation though the strength of the increase is dependent on a related climate change (Xu et al., 2007). An earlier modelling study revealed that $\mathrm{CO}_{2}$ enhancement together with a warmer and a more humid climate would cause an increase in NPP $(\mathrm{Ni}, 2000)$. Investigations show that soil carbon and nitrogen cycling in a grassland ecosystem are much more responsive to increases in the past than to those predicted for the coming century (Gill et al., 2002). Körner (2006) pointed out that the relative influence of any given increment of $\mathrm{CO}_{2}$ concentration declines with the absolute concentration which is confirmed by our modelling results which similarly do not show a linear relationship.

\section{Conclusions}

Numerous pollen records from across the upper Tibetan Plateau indicate that Kobresia-dominated high-alpine meadow invaded alpine steppes during the mid- to late-Holocene. However, our investigation using a pollen-moisture transfer function yielded that this marked vegetation change cannot be satisfactorily explained by climate change. A literature review did not reveal convincing evidence for any widespread human impact on mid-Holocene vegetation. Here we propose that the vegetation changes can, at least partly, be interpreted as a response to Holocene $\mathrm{CO}_{2}$ concentration changes. Our theoretical argument is based on the findings that high-elevation vegetation is particularly sensitive to $\mathrm{CO}_{2}$ changes due to lowered $\mathrm{CO}_{2}$ partial pressure; that water conservation of steppe vegetation in response to experimental $\mathrm{CO}_{2}$ enrichment was of the same order of magnitude as inferred from mid-to late Holocene Tibetan pollen records, and that modern remote sensing-aided vegetation monitoring of the Central Tibetan Plateau yielded an increase in biomass, most probably as an response to modern $\mathrm{CO}_{2}$ increase, despite increasing land-use by herding.

\section{Acknowledgements}

We appreciate the helpful comments of Suzanne Leroy and Qinghai Xu. We thank Cathy Jenks for invaluable help with editing of the manuscript. This is publication no. A289 from the Bjerknes Centre for Climate Research. This study was funded by the German Research Foundation.

\section{Appendix A. Supplementary material}

Supplementary data associated with this article can be found, in the online version, at doi:10.1016/j.quascirev.2011.03.007.

\section{References}

Ainsworth, E.A., Rogers, A., 2007. The response of photosynthesis and stomatal conductance to rising $\mathrm{CO}_{2}$ : mechanisms and environmental interactions. Plant, Cell and Environment 30, 258-270.

Aldenderfer, M.S., 2007. Modeling the Neolithic on the Tibetan Plateau. Developments in Quaternary Sciences 9, 151-165.

Aldenderfer, M.S., Zhang, Y., 2004. The prehistory of the Tibetan Plateau to the seventh century A.D.: perspectives and research from China and the West since 1950. Journal of World Prehistory 18, 1-55.

Arp, W.J., 1991. Effects of source-sink relations on photosynthetic acclimation to elevated $\mathrm{CO}_{2}$. Plant, Cell and Environment 14, 869-875.

Birks, H.J.B., 1998. Numerical tools in palaeolimnology - progress, potentialities, and problems. Journal of Paleolimnology 20, 307-332.

Böhner, J., 2005. Advancements and new approaches in climate spatial prediction and environmental modelling. Arbeitsberichte des Geographischen Institutes der Humboldt-Universität zu Berlin 109, 49-90.

Böhner, J., 2006. General climatic controls and topoclimatic variations in Central and High Asia. Boreas 35, 279-295.

Böhner, J., Antonic, O., 2008. In: Hengl, T., Reuter, H.I. (Eds.), Geomorphometry: Concepts, Software, Applications. Developments in Soil Science Land-surface parameters specific to topo-climatology, vol. 33. Elsevier, pp. 195-226.

ter Braak, C.J.F., Juggins, S., 1993. Weighted averaging partial least squares regression (WA-PLS): an improved method for reconstructing environmental variable from species assemblages. Hydrobiologia 269/270, 485-502.

Brantingham, P.J., Gao, X., 2006. Peopling of the northern Tibetan Plateau. World Archaeology 38, 387-414.

Brantingham, P.J., Gao, X., Olsen, J.W., Ma, H., Rhode, D., Zhang, H., Madsen, D.B., 2007. A short chronology for the peopling of the Tibetan Plateau. Developments in Quaternary Sciences 9, 129-150.

Bresson, C.C., Kowalski, A.S., Kremer, A., Delzon, S., 2009. Evidence of altitudinal increase in photosynthetic capacity: gas exchange measurements at ambient and constant $\mathrm{CO}_{2}$ partial pressures. Annals of Forest Science 66, 505

Chu, D., Lu, L., Zhang, T., 2007. Sensitivity of normalized difference vegetation index (NDVI) to seasonal and interannual climate conditions in the Lhasa area, Tibetan Plateau, China. Arctic, Antarctic and Alpine Research 39, 635-641.

Cui, X., Tang, Y., Gu, S., Shi, S., Nishimura, S., Zhao, X., 2004. Leaf orientation, incident sunlight, and photosynthesis in alpine species Saussurea superba and Genziana straminea on the Qinghai-Tibet Plateau. Arctic, Antarctic, and Alpine Research $36,219-228$.

Dearing, J.A., Jones, R.T., Shen, J., Yang, X., Boyle, J.F., Foster, G.C., Crook, D.S., Elvin, M.J.D., 2008. Using multiple archives to understand past and present climate-human-environment interactions: the lake Erhai catchment, Yunnan Province, China. Journal of Paleolimnology 40, 3-31.

Elsig, J., Schmitt, J., Leuenberger, D., Schneider, R., Eyer, M., Leuenberger, M., Joos, F., Fischer, H., Stocker, T.F., 2009. Stable isotope constraints on Holocene carbon cycle changes from an Antarctic ice core. Nature 461, 507-510.

FAO, 1995. Digital Soil Map of the World and Derived Soil Properties. Food and Agriculture Organization, Rome. 
Fay, P.A., Kelley, A.M., Procter, A.C., Hui, D., Jin, V.L., Jackson, R.B., Johnson, H.B., Polley, H.B., 2009. Primary productivity and water balance of grassland vegetation on three soils in a continuous $\mathrm{CO}_{2}$ gradient: initial results from the Lysimeter $\mathrm{CO}_{2}$ gradient experiment. Ecosystems 12, 699-714.

Fleitmann, D., Burns, S., Mudelsee, M., Neff, U., Kramers, U., Mangini, A., Matter, A. 2003. Holocene forcing of the Indian monsoon recorded in a stalagmite from southern Oman. Science 300, 1737-1739.

Friedli, H., Lötscher, H., Oeschger, H., Siegenthaler, U., Stauffer, B., 1986. Ice core record of the ${ }^{13} \mathrm{C} /{ }^{12} \mathrm{C}$ ratio of atmospheric $\mathrm{CO}_{2}$ in the past two centuries. Nature 324, 237-238.

Fu, Y., Zheng, Z., Yu, G., Sun, X., Shi, P., Wang, Y., Zhao, X., 2009. Environmental controls on carbon fluxes over three grassland ecosystems in China. Biogeosciences Discussions 6, 8007-8040.

Gill, R.A., Polley, H.W., Johnson, H.B., Anderson, L.J., Maherall, H., Jackson, R.B., 2002. Nonlinear grassland responses to past and future atmospheric $\mathrm{CO}_{2}$. Nature 417 , 279-282.

Gu, S., Tang, Y., Du, M., Kato, T., Li, Y., Cui, X., Zhao, X., 2003. Short-term variation of $\mathrm{CO}_{2}$ flux in relation to environmental controls in an alpine meadow on the Qinghai-Tibetan Plateau. Journal of Geophysical Research 108. doi:10.1029/ 2003JD003584.

Guiot, J., Hai, B., Jiang, W., Luo, Y., 2008. East Asian Monsoon and paleoclimatic data analysis: a vegetation point of view. Climate of the Past 4, 137-145.

Guo, S., Savolainen, P., Su, J., Zhang, Q., Qi, D., Zhou, J., Zhong, Y., Zhao, X., Liu, J., 2006. Origin of mitochondrial DNA diversity of domestic yaks. BMC Evolutionary Biology 6, 73.

He, J.-S., Wang, Z., Wang, X., Schmid, B., Zuo, W., Zhou, M., Zheng, C., Wang, M., Fang, J. 2006. A test of the generality of leaf trait relationships on the Tibetan Plateau. New Phytologist 170, 835-848.

Herzschuh, U., 2006. Palaeo-moisture evolution at the margins of the Asian monsoon during the last $50 \mathrm{ka}$. Quaternary Science Reviews 25, 163-178.

Herzschuh, U., Kürschner, H., Mischke, S., 2006a. Temperature variability and vertical vegetation belt shifts during the last $\sim 50,000$ yrs in the Qilian Mountains (NE margin of the Tibetan Plateau, China). Quaternary Research 66, 133-146.

Herzschuh, U., Winter, K., Wünnemann, B., Li, S., 2006b. A general cooling trend on the central Tibetan Plateau throughout the Holocene recorded by the Lake Zigetang pollen spectra. Quaternary International 154-155, 113-121.

Herzschuh, U., Kramer, A., Mischke, S., Zhang, C., 2009. Quantitative climate and vegetation trends since the late glacial on the northeastern Tibetan Plateau deduced from Koucha Lake pollen record. Quaternary Research 71, 162-171.

Herzschuh, U., Birks, H.J.B., Mischke, S., Zhang, C., Böhner, J., 2010a. A modern pollen-climate calibration set based on lake sediments from the Tibetan Plateau and its application to a Late-Quaternary pollen record from the Qilian Mountains. Journal of Biogeography 37, 752-766.

Herzschuh, U., Birks, H.J.B., Ni, J., Zhao, Y., Liu, H., Liu, X., Grosse, G., 2010b. Holocene land-cover changes on the Tibetan Plateau. The Holocene 20, 91-104.

Herzschuh, U., Birks, H.J.B., Liu, X., Kubatzki, C., Lohmann, G., 2010c. What caused the mid-Holocene forest decline on the eastern Qinghai-Tibetan Plateau? Global Ecology and Biogeography 19, 278-286.

Hou, X. (Ed.), 2001. Vegetation Atlas of China. Science Press, Beijing.

Indermühle, A., Stocker, T.F., Joos, F., Fischer, H., Smith, H.J., Wahlen, M., Deck, B., Mastroianni, D., Tschumi, J., Blunier, T., Meyer, R., Stauffer, B., 1999. Holocene carbon-cycle dynamics based on $\mathrm{CO}_{2}$ trapped in ice at Taylor Dome, Antarctica. Nature 398, 121-126.

IPCC, 2007. Climate change 2007: the physical science basis. In: Solomon, S., Qin, D., Manning, M. (Eds.), Contribution of Working Group I to the Fourth Assessment Report of the Intergovernmental Panel on Climate Change. Cambridge University Press, New York.

Jacobson, G.L., 1988. Ancient permanent plots: sampling in paleovegetational studies. In: Huntley, B., Webb III, T. (Eds.), Vegetation History. Kluwer, Dordrecht, pp. 3-16.

Juggins, S., 2003. User Guide C2 - A Program for Analysing and Visualising Palaeoenvironmental Data. Department of Geography, University of Newcastle, UK.

Kaplan, J.O., Bigelow, N.H., Prentice, I.C., Harrison, S.P., Bartlein, P.J., Christensen, T.R., Cramer, W., Matveyeve, N.V., McGuire, A.D., Murray, D.F., Razzhivin, V.Y., Smith, B., Walker, D.A., Anderson, P.M., Andreev, A.A., Brubaker, L.B., Edwards, M.E., Lozhkin, A.V., 2003. Climate change and Arctic ecosystems: 2. Modeling, paleodata-model comparisons, and future projections. Journal of Geophysical Research 108, 8171. doi:10.1029/2002JD002559.

Knudsen, M.F., Riisager, P., 2009. Is there a link between Earth's magnetic field and low-latitude precipitation? Geology 37, 71-74.

Körner, $\mathrm{Ch}, 2006$. Plant $\mathrm{CO}_{2}$ responses: an issue of definition, time and resource supply. New Phytologist 172, 393-411.

Körner, Ch., Diemer, M., 1987. In situ photosynthetic responses to light, temperature and carbon dioxide in herbaceous plants from low and high altitude. Functional Ecology 1, 179-194.

Körner, Ch., Diemer, M., 1994. Evidence that plants from high-altitude retain their greater photosynthetic efficiency under elevated $\mathrm{CO}_{2}$. Functional Ecology 8 , 58-68.

Körner, Ch., Farquhar, G.D., Roksandic, Z., 1988. A global survey of carbon isotope discrimination in plants from high altitudes. Oecologica 74, 623-632.

Körner, Ch., Diemer, M., Schäppi, B., Niklaus, P., Arnone, J., 1997. The response of alpine grassland to four seasons of $\mathrm{CO}_{2}$ enrichment: a synthesis. Acta Oecologica $18,165-175$.

Kramer, A., Herzschuh, U., Mischke, S., Zhang, C., 2010a. Holocene treeline shifts and monsoon variability in the Hengduan Mountains (southeastern Tibetan
Plateau), implications from palynological investigations. Palaeogeography, Palaeoclimatology, Palaeoecology 286, 23-41.

Kramer, A., Herzschuh, U., Mischke, S., Zhang, C., 2010b. Late glacial vegetation and climate oscillations on the southeastern Tibetan Plateau inferred from the Lake Naleng pollen profile. Quaternary Research 73, 324-335.

Laskar, J., Robutel, P., Joutel, F., Gastineau, M., Correia, A.C.M., Levrard, B., 2004 A long-term numerical solution for the insolation quantities of the Earth Astronomy and Astrophysics 428, 261-285.

Lim, C., Kafatos, M., Megonigal, P., 2004. Correlation between atmospheric $\mathrm{CO}_{2}$ concentration and vegetation greenness in North America: $\mathrm{CO}_{2}$ fertilization effect. Climate Research 28, 11-22.

Liu, Z., Harrison, S.P., Kutzbach, J., Otto-Bliesner, B., 2004. Global monsoons in the mid-Holocene and oceanic feedback. Climate Dynamics 22, 157-182.

Lucash, M.S., Farnsworth, B., Winner, W.E., 2005. Response of sagebush steppe to elevated $\mathrm{CO}_{2}$ and soil temperature. Western North American Naturalist 65, 80-86.

McMurtrie, R.E., Norby, R.J., Medlyn, B., Dewar, R.C., Pepper, D.A., Reich, P.B. Barton, C.V.M., 2008. Why is plant-growth response to elevated $\mathrm{CO}_{2}$ amplified when water is limiting, but reduced when nitrogen is limiting? A growthoptimisation hypothesis. Functional Plant Biology 35, 521-534.

Meyer, M.C., Hofmann, Ch.-Ch., Gemmell, A.M.D., Haslinger, E., Häusler, H. Wangda, D., 2009. Holocene glacier fluctuations and migration of Neolithic yak pastoralists into the high valleys of northwest Bhutan. Quaternary Science Reviews 28, 1217-1237.

Miehe, G., Miehe, S., Kaiser, K., Liu, J., Zhao, X., 2008. Status and dynamics of the Kobresia pygmaea ecosystem on the Tibetan Plateau. Ambio 37, 272-279.

Miehe, G., Miehe, S., Kaiser, K., Reudenbach, C., Behrendes, L., Duo, L., Schlütz, F. 2009. How old is pastoralism in Tibet? An ecological approach to the making of a Tibetan landscape. Palaeogeography, Palaeoclimatology, Palaeoecology 276 130-147.

Monnin, E., Steig, E.J., Siegenthaler, U., Kawamura, K., Schwander, J., Stauffer, B. Stocker, T.F., Morse, D.L., Barnola, J.-M., Bellier, B., Raynaud, D., Fischer, H., 2004 Evidence for substantial accumulation rate variability in Antarctica during the Holocene, through synchronization of $\mathrm{CO}_{2}$ in the Taylor Dome, Dome $\mathrm{C}$ and DML ice cores. Earth and Planetary Science Letters 224, 45-54.

Morgan, J.A., Pataki, D.E., Körner, Ch., Clark, H., Del Grosso, S.J., Grünzweig, J.M., Knapp, A.K., Mosier, A.R., Newton, P.C.D., Niklaus, P.A., Nippert, J.B. Nowak, R.S., Parton, W.J., Polley, H.W., Shaw, M.R., 2004. Water relations in grassland and desert ecosystems exposed to elevated atmospheric $\mathrm{CO}_{2}$. Oecologia 140, 11-25.

Nelson, J.A., Morgan, J.A., LeCain, D.R., Mosier, A.R., Milchunas, D.G., Parton, W.J. 2004. Elevated $\mathrm{CO}_{2}$ increases soil moisture and enhances plant water relation in a long-term field study in the semi-arid shortgrass steppe of Northern Colorado. Plant Soil 259, 169-179.

Ni, J., 2000. A simulation of biomes on the Tibetan Plateau and their responses to global climate change. Mountain Research and Development 20, 80-89.

Ni, J., Herzschuh, U. Simulating biomes on the Tibetan Plateau using an improved global vegetation model. Arctic, Antarctic, and Alpine Research, in press.

Niklaus, P.A., Körner, Ch, 2004. Synthesis of a six-year study of calcareous grassland responses to in situ $\mathrm{CO}_{2}$ enrichment. Ecological Monographs 74, 491-511.

Niklaus, P.A., Leadley, P.W., Schmid, B., Körner, Ch, 2001. A long-term field study on biodiversity $\times$ elevated $\mathrm{CO}_{2}$ interactions in grasslands. Ecological Monographs 71, 341-356.

Nowak, R.S., Ellsworth, D.S., Smith, S.D., 2004. Functional responses of plants to elevated atmospheric $\mathrm{CO}_{2}$ - do photosynthetic and productivity data from FACE experiments support early predictions? New Phytologist 162, 253-280.

Olivo, N., Martinez, C.A., Oliva, M.A., 2002. The photosynthetic response to elevated $\mathrm{CO}_{2}$ in high altitude potato species (Solanum curtilobum). Photosynthetica 40 303-313.

Prentice, I.C., Harrison, S.P., 2009. Ecosystem effects of $\mathrm{CO}_{2}$ concentration: evidence from past climates. Climate of the Past 5, 297-307.

Polley, H.W., Johnson, H.B., Marino, B.D., Mayeux, H.S., 1993. Increases in $C_{3}$ plant water-use efficiency and biomass over glacial to present $\mathrm{CO}_{2}$ concentrations. Nature 361, 61-64.

Potvin, C., Vasseur, L., 1997. Long-term $\mathrm{CO}_{2}$ enrichment of a pasture community species richness, dominance, and succession. Ecology 78, 666-677.

Piao, S., Fang, J., He, J., 2006. Variations in vegetation net primary production in the Qinghai-Xizang Plateau, China, from 1982 to 1999. Climatic Change 74, 253-267.

Pyankov, V.I., Kondrachuk, A.V, 2003. Basic types of structural changes in the leaf mesophyll during adaptation of eastern Pamir Plants to mountain conditions. Russian Journal of Plant Physiology 50, 28-35.

Reich, P.B., Oleksyn, J., 2004. Global patterns of plant leaf $\mathrm{N}$ and $\mathrm{P}$ in relation to temperature and latitude. Proceedings of the National Academy of Sciences U. S. A., 11001-11006.

Ruddiman, W.F., 2003. The anthropogenic greenhouse era began thousands of years ago. Climatic Change 61, 261-293.

Ruddiman, W.F., Ellis, E.C., 2009. Effect of per-capita land-use changes on Holocene forest clearance and $\mathrm{CO}_{2}$ emissions. Quaternary Science Reviews 28, 2011-3015.

Schlütz, F. Lehmkuhl, F, 2009. Holocence climatic change and the nomadic Anthropocene in Eastern Tibet: palynological and geomorphological results from Nianbaoyeze Mountains. Quaternary Science Reviews 28, 1449-1471.

Shen, C., 2003. Millennial-scale variations and centennial-scale events in the Southwest Asian monsoon: pollen evidence from Tibet. PhD dissertation, Lousiana State University. Available from: http://etd.lsu.edu/docs/available/etd0402103-165113/unrestricted/Shen_dis.pdf. 
Shen, J., Liu, X., Wang, S., Matsumoto, R., 2005. Palaeoclimatic changes in the Qinghai Lake area during the last 18,000 years. Quaternary International 136, 131-140.

Shen, C., Liu, K.-B., Tang, L., Overpeck, J.T., 2006. Quantitative relationships between modern pollen rain and climate in the Tibetan Plateau. Review of Palaeobotany and Palynology 140, 61-77.

Shen, C., Liu, K.-B., Morrill, C., Overpeck, J.T., Peng, J., Tang, L., 2008. Ecotone shift and major droughts during the mid-late Holocene in the central Tibetan Plateau. Ecology 89, 1079-1088.

Song, M.H., Zhou, C.P., Ouyang, H., 2005. Simulated distribution of vegetation types in response to climate change on the Tibetan Plateau. Journal of Vegetation Science 16, 341-350.

Song, M., Duan, D., Chen, H., Hu, Q., Zhang, F., Xu, X., Tian, Y., Hua, O., Peng, C., 2008. Leaf $\delta^{13} \mathrm{C}$ reflects ecosystem patterns and responses of alpine plants to the environments of the Tibetan Plateau. Ecography 31, 499-508.

Sun, X., Du, N., Chen, Y., Gu, Z., Liu, J., Yuan, B., 1993. Holocene palynological records in Lake Selincuo, northern Xizang. Acta Botanica Sinica 35, 943-950 (in Chinese with English abstract).

Terashima, I., Masuzawa, T., Obba, H., Yokoi, Y., 1995. Is photosynthesis suppressed at higher elevation due to low $\mathrm{CO}_{2}$ pressure? Ecology 76, 2663-2668.

Wang, Y., Cheng, H., Edwards, R.L., He, Y., Kong, X., An, Z., Wu, J., Kelly, M. Dykoski, C.A., Li, X., 2005. The Holocene Asian monsoon: links to solar changes and North Atlantic climate. Science 308, 854-857.

Wei, K., Jia, G., 2009. Soil n-alkane $\delta^{13} \mathrm{C}$ along a mountain slope as an integrator of altitude effect on plant species $\delta$ C. Geophysical Research Letters 36, L11401.

Wischnewski, J., Herzschuh, U., Mischke, S., Wang, Y., 2011. Reconstructing climate variability on the northeastern Tibetan Plateau since the last late glacial a mulit-proxy, dual-site approach comparing terrestrial and aquatic signals. Quaternary Science Reviews 30, 82-97.
Wu, H., Guiot, J., Brewer, S., Guo, Z., 2007. Climatic changes in Eurasia and Africa at the last glacial maximum and mid-Holocene: reconstruction from pollen data using inverse vegetation modelling. Climate Dynamics 29, 211-229.

Wu, G.-L., Du, G.-Z., Liu, Z.-H., Thirgood, S., 2009. Effect of fencing and grazing on a Kobresia-dominated meadow in the Qinghai-Tibetan Plateau. Plant Soil 319, 115-126.

Xu, L., Zhang, X., Shi, P., Li, W., He, Y., 2007. Modelling the maximum apparent quantum use efficiency of alpine meadow ecosystem of Tibetan Plateau. Ecological Modelling 208, 129-134.

Yang, Y.H., Fang, J.Y., Pan, Y.D., Ji, C.J., 2009. Aboveground biomass in Tibetan grasslands. Journal of Arid Environments 73, 91-95.

Yasunari, T., 2006. Land-atmosphere interaction. In: Wang, B. (Ed.), The Asian Monsoon. Springer, Berlin, pp. 459-478.

Zhang, Y., Tang, Y., 2005. Inclusion of photoinhibition in simulation of carbon dynamics of an alpine meadow on the Qinghai-Tibetan Plateau. Journal of Geophysical Research 110, G01007. doi:10.1029/2005JG000021.

Zhang, J., Yao, F., Zheng, L., Yang, L., 2007a. Evaluation of grassland dynamics in the Northern-Tibet Plateau of China using remote sensing and climate data. Sensors 7, 3312-3328

Zhang, Y., Liu, C., Tang, Y., Yang, Y., 2007b. Trends in pan evaporation and reference and actual evapotranspiration across the Tibetan Plateau. Journal of Geophysical Research 112, D12110. doi:10.1029/2006JD008161.

Zhao, Y, Herzschuh, U., 2009. Modern pollen representation of source vegetation in the Qaidam Basin and surrounding mountains, north-eastern Tibetan Plateau. Vegetation History and Archaeobotany 18, 245-260.

Zhao, Y., Braconot, P., Marti, O., Harrison, S.P., Hewitt, C., Kitoh, A., Liu, Z., Mikolajewicz, U., Otto-Bliesner, B., Weber, S.L., 2005. A multi-model analysis of the role of the ocean on the African and Indian monsoon during the midHolocene. Climate Dynamics 25, 777-800. 